\title{
Leadership in Early Childhood Education Contexts: Looks, Roles, and Functions
}

\author{
Charles Kivunja \\ School of Education, The University of New England, Armidale, Australia \\ Email: ckivunja@une.edu.au
}

Received 12 August 2015; accepted 13 September 2015; published 16 September 2015

Copyright (C) 2015 by author and Scientific Research Publishing Inc.

This work is licensed under the Creative Commons Attribution International License (CC BY). http://creativecommons.org/licenses/by/4.0/

(c) (i) Open Access

\begin{abstract}
Situated in the field of early childhood education (ECE), this paper uses literature on educational leadership to answer four questions about leadership in ECE contexts. Firstly, what is leadership and how important is it for the success of an organisation? Secondly, what does it look like in ECE? Thirdly, what does leadership in ECE involve? And fourthly, how does efficient and effective leadership function in an ECE context? It is important to answer these questions because there is an understanding that leadership in ECE contexts is unlike leadership in other educational institutions. It requires special administrative and managerial skills to plan, organise, lead, control and direct the operations in the ECE context, as well as leadership skills to provide an organisational vision, direction and aculturation. An understanding of what leadership in ECE contexts looks like, its roles and functions can inform ECE leaders in ways that help them to improve the efficiency and effectiveness of their educational institution.
\end{abstract}

\section{Keywords}

Educational Leadership, Early Childhood Education Contexts, Managerial Skills, Organisational Vision, Aculturation, Organisational Structural Cultural Synergies

\section{Meaning and Importance of Leadership}

When discussing a term such as leadership which has been defined in many different ways, it is prudent to start the discussion with Hammersley's (1998) advice that we should define the terms we use so as to acquaint the reader with "statements about how the author is going to use a term, about what meaning is to be associated with it” (p. 80). Whereas numerous definitions of leadership exist, one that appears to capture very well the central meaning of leadership is provided by Robbins, Millet, Cacciope, \& Waters (1998) who say leadership is "the ability to influence others towards the achievement of goals that contribute to a worthwhile purpose” (p. 396). This definition appears to strike a code of consensus among leaders in the field that leadership is about influen- 
cing and enabling followers to work towards the realization of organizational goals. This is important because the organizational goals are the real worthwhile purpose for the existence of any organization.

And so leadership is about enabling change that helps followers to make a contribution to this change. This resonates well with Fullan (2000) who sees the new meaning of leadership as leadership which makes "each and every educator strives to be an effective change agent” (p. 13). Defining leadership this way makes it very clear to the reader that leadership is essential for the success of any educational organization. For example, Mulford, Silins, \& Leithwood (2004) say, "Leadership we know makes all the difference in success or failure of organizations" (p. ii). Similarly, Truskie (2002) asserts that, "there is a direct link between leadership, organizational culture and performance” (p. 1). Silins \& Mulford (2002) also point to the important role of leadership when they propose that "leadership ... (has) been shown to influence what happens in the core business of the school: the teaching and learning” (p. 443). Fligsten \& Freeland (1995) extend the importance of leadership beyond the locality of the organization when they assert that the ability of organizational leaders to solve internal resource problems is a function of their abilities, knowledge and links with the outside world. This external linkage highlights the importance of leadership to coordinate and to harmonize the structural-cultural dynamics (Kivunja \& Power, 2006) which foster organizational development and learning in a way that makes a positive difference to the lives of students in an ECE context.

As well articulated by Pace (2002), leadership is such an important part of any workplace such that the workplace "cannot be understood clearly without understanding the function of leadership in the system" (p. 33). Scott (1999) also emphasizes the importance of effective leadership in the "effective management of educational change” (p. 50), within a school. Fullan (2001, p. 261), also agrees when he writes:

Nowhere is the focus on the human element more prevalent

than in the recent recognition of the importance of strong

and effective leadership. (And he later added:) effective school

leaders are the key to large-scale, sustainable education reform.

(Fullan, 2004, p. 15)

The importance of leadership is also well highlighted by Mulford (2003) who argues that "whatever elements of restructuring of public schooling ... are employed, they all have in common a strong dependence on effective school leadership for their successful implementation” (p. 8). Moreover, Mulford, Silins, \& Leithwood (2004) argue that, "leadership that makes a difference in organizational learning and student outcomes, is transformational and distributed" (p. 6). Barker \& Coy (2004) also say that, "the success or failure of cultural change will depend on the attitude of the leadership team. They must be prepared to champion the beliefs and values that underpin the emerging culture" (p. 13). Additionally these authors affirm that at the heart of the cultural change process "lies the integrity of the leader, the example set by the leader and the trust established by the leader" (Barker \& Coy, 2004: p. 61). As Hackman \& Wageman (2005) rightly assert, "traditionally, leaders' behaviors and decisions, have been viewed as highly consequential for effectiveness of organizations” (p. 277).

Thus, there is a repeated pattern in consensus among leaders in educational change literature that leadership plays a key role in the structural and cultural dynamics designed for school improvement. Leadership is seen as the glue that holds together the structural and cultural dynamics within an organization through the execution of informational, interpersonal and decisional roles. As Scott (1999: p. 93) says:

Effective leaders know how best to shape culture, develop a positive

working climate, communicate their service's mission and priorities,

coordinate quality assurance and enhancement in learning programs

and reward staff as they grapple with ongoing change.

Thus, leadership is about enabling followers to bring about desired change by setting up organizational structures which enable the cultural synergies within the ECE context to be shared and dispersed within the ECE organization between and among all members involved in ECE. Leadership is important because it is responsible for calling for a commitment and passion from every member of the ECE setting to make a contribution which results in a positive difference in the lives of the children in the ECE context and to help lay the foundation which will help them to develop into productive citizens who will be able to live and work productively in increasingly dynamically complex societies. This, according to Fullan (2000), is "the moral purpose of education" (p. 4). A conceptualization of leadership as an agent which enables the pursuit of this moral purpose by every- 
one involved in ECE sees leadership not as the preserve of one leader but as distributed across the membership of an organization such that “leadership is everyone’s business” (Kouzes \& Posner, 2003: p. 383).

\section{What Leadership Looks Like in an Early Childhood Context}

Whereas the above section has outlined a generic understanding of leadership and its importance, the work of many leaders in the field of ECE (including Arthur, Beecher, Death, Dockett, \& Farmer (2007); Becker \& Becker (2009); Belsky (1988); Ebbeck, \& Yim (2009); Follari (2007); McCrea (2015); Ochiltree (1994); Sims (1999, 2009); Wood \& Attfield, (2005), suggests that it is helpful to articulate what leadership looks like specifically in an ECE setting. McCrea (2015) deals with this topic very well when she suggests that leadership in an ECE context is about bringing improvement through influencing people, in places where ECE takes place, and engaging in and encouraging the conduct of professional and ethical practices. Let's take a brief look at each of these 3Ps of McCrea's proposition.

\subsection{People in Early Childhood Educational Contexts}

People in an ECE setting influence what happens in the setting and likewise, the settings influence people in the ECE setting (McCrea, 2015). People who participate in one way or another in ECE settings fall in a wide variety of roles. They include children, parents or caregivers of the children, child center director, child center manager, administrator, coordinator, assistant, development officer, accountant, teacher, educator, bus driver, gardener, and any staff members that might be at the ECE setting on a casual basis. Quite often these people come from a broad range of backgrounds, socially, culturally, economically, politically, morally and in many other ways, and they are therefore culturally and linguistically diverse. These peoples' norms, personal beliefs, values, and assumptions (Schein, 2005), have impacts on the children in the ECE setting. It is incumbent upon the leadership to ensure that the people charged with the responsibility for the wellbeing of children under their care in an ECE setting, particularly the professional staff, are equipped and empowered adequately to deliver high quality services that are not only child-friendly but also parent or care-giver-friendly, respectful and which meet the expectations of all stakeholders. Only when these people deliver high quality service can the long-term survival of an ECE setting be sustained.

\subsection{Places That Comprise Early Childhood Educational Contexts}

Places that comprise ECE settings are referred to by all sorts of names: kindergarten, preparatory, pre-primary, reception, transition (Dowling \& O’Malley, 2009), childcare centers, preschools, playschools, nurseries, or just sites for early childhood education (Davis, 2010), family day care centers, play centers, integrated children's centers, early learning centers, nanny services centers, or the more recently introduced term, early childhood education center (Ailwood, 2007). Irrespective of what label is used, we know that apart from the home, the ECE place is where children spend most of their early years. Leadership in such a place, therefore, has potential to mold a child's approach and appreciation of humanity. This is the place where the child not only develops his or her mother tongue, but also has the opportunity to learn other languages through contact and communication with the other children that s/he comes in contact and communicates with at the ECE site. It is important therefore for leadership at this level to create a quality learning and living environment (Carnes (2011), in which the children can be allowed to be children, as they relate and interact with each other and with the caring staff, away from the hustle and hectic life of the fast moving economy of the $21^{\text {st }}$ century).

Leading such a place also requires the leader to create a place in which staff enjoy comfortable or even amicable relationships among themselves and with the children so that high quality interpersonal relationships are encouraged, ideas shared, respected and considered honestly with due regard. The ECE setting leader has a duty to extend the ECE place beyond the immediate surroundings of the particular setting so as to create linkages with external stakeholders such as government departments, professional organizations, educational institutions, professional organizations as well as local and regional community and business centers.

\subsection{Practices That Characterize Early Childhood Educational Contexts}

The practices include all the professional roles that the ECE leader has to deal with. As discussed further below, the different roles can be grouped into four, which McCrea (2015) characterizes as team stakeholder, policy de- 
signer, pedagogy creator and rights' advocate. The practices that characterize the role of a team stakeholder include sourcing and recruiting new staff to fill vacancies, assigning responsibilities to each member of staff, providing support and mentoring for staff, creating opportunities for staff professional development, creating harmonious working relationships and if conflicts occur, resolving them amicably, organizing and conducting staff meetings, attending to each staff member's needs and providing for occupational health and safety in the ECE setting. The practices that characterize the role of a policy designer in an ECE setting include a multitude of professional actions necessary to make sure that the policies designed to provide for governance in the ECE setting are legal, fair, just, democratic and transparent, minimize risk to the children and anybody involved with the ECE setting, provide guidelines for all stakeholders of the ECE site, and having protocols that are flexible for the efficiency of the ECE setting (Bryant \& Gibbs, 2013). Those of a pedagogy creator include every practice in the ECE setting that is intended to give young children an authentic pedagogy. But in an ECE setting, the focus is not just on teaching, learning, assessment and curriculum as delivered by early childhood educators-the orthodoxy understanding of pedagogy — but also on the everyday wellbeing of the children. As pedagogy creators, these educators design, develop and make available educational resources to be used in the ECE setting to help children learn but also to be children. As noted by Semann and Soper (2012), these pedagogy creators contribute to the vision and strategies that facilitate knowledge construction in an ECE setting. The practices of a rights' advocate include the rather political ECE workplace maneuvers undertaken and voices raised to advance the wellbeing of young children. These measures are not limited to the ECE physical settings or locale but extend far beyond such confines to include life beyond the ECE setting gates, "out there in the wider world with beyond-the-fence communities” (McCrea, 2015: p. 148). Each of these categories is delineated further in the following section.

\section{What Does Leadership in Early Childhood Education Involve?}

As stated above, an excellent depiction of what leadership in ECE involves is captured very well by McCrea (2015) who characterizes all that is involved into four roles, namely that of a team leader, a policy designer, a pedagogy creator and a rights advocate. Each of these roles is unpacked here briefly to shed some more light on what leadership in an ECE setting involves.

\subsection{Leading People in ECE Settings as a Team Stakeholder}

Leadership of participants in an ECE setting conceptualized as a team leader helps to articulate the role as one involving the leader not only as one of the agents of change, but also a follower at the same time. For in a team, the leader is the captain, but s/he has to play his or her part and help the team to achieve victory, and has personal interest in the success of the team. And so, the pursuit of organizational goals in an ECE setting involves all participants, with the leader as the provider of the vision, (Caldwell, 2006), organizational structures and resources (Brundrett \& Crawford, 2008) that are then used by the team to work together for the success and sustainability of the organization. Leading people in an ECE setting therefore requires not only the five principles of cooperative learning which Johnson \& Johnson (1994) as well as Kagan (1994) articulate as Positive Interdependence, Individual Accountability, Equal Participation, Group Processing and Simultaneous Interaction, but also the Super 4Cs of Critical thinking and problem solving, Collaboration, Creativity and innovation, as well as Communication (Kivunja, 2015a).

In providing for Positive Interdependence the ECE leader impresses his or her participants that they need to work together so closely such that there is the understanding that we shall "sink or swim together" (Johnson \& Johnson, 2009: p. 2). This principle exists when participants in an ECE setting realize and believe they can achieve their personal goals if, and only if, the other team members also reach their goals. In providing for Individual Accountability among members of the ECE setting, the ECE leader requires that members of the team feel they have a sense of individual responsibility for the performance of the tasks and achievement of the common goals. Each member in the ECE setting feels that they have a responsibility to contribute to the task assigned to the team because they have something valuable that they can offer. In providing for Equal Participation by every member of the ECE setting, the leader's role is to ensure that each team member assumes an equal share of the tasks that need to be completed in the ECE setting. The ECE leader needs to ensure that equal opportunity is provided to the members and that each member of the team makes a contribution to the task according to their personal best. This way, the team's goal is achieved through promotive interaction among all members of the ECE team. For Group 
processing to occur in the ECE setting, the leader needs to give participants the opportunity to reflect on learning experiences during teamwork, so they understand better what happened during the cooperative activities, to evaluate how they have achieved the set goals, to discuss their overall experiences among themselves, to review which actions were helpful and which ones were not, decide on which actions to keep for future use, to decide on which actions to change in future teamwork, to set goals for future work, and to strategize for future success. To provide for Simultaneous Interaction the ECE leader needs to ensure that team members engage in interpersonal and group interactions, get to know each member of the team, develop trust for each member of the team, actively listen to each member of the team, communicating clearly and accurately, taking turns, opportunity to state ideas freely, accepting responsibility to contribute and for what each member contributes, providing constructive criticism to other members of the team, accepting constructive criticism from other members of the team, sharing tasks, engaging in democratic decision making, being sensitive to team members' different perspectives, clarifying differences, accepting and supporting each other, avoiding conflict, and resolving conflict constructively, if it occurs (Gillies \& Boyle, 2013). In leading people in the ECE setting as a team, the leader needs to ensure that the people exercise critical thinking all the time to maximize the rationality of their decision-making and problem solving. They should work collaboratively and in a manner that supports each other. They should also be creative and innovative in the way they engage in the activities in the ECE setting and they should communicate effectively with each other.

\subsection{Leading People in ECE Settings as a Policy Designer}

Leading people in an ECE setting as a policy designer involves coming up with the vision for the big picture for the ECE. It requires the leader to be able to creatively influence children and staff in ECE to engage positively in the learning, teaching, educating and growing up that take place during ECE. Designers are by profession able to critique their creations, to reflect on how their present designs are meeting client demand and to plot a different course or come up with an entirely new design to maintain relevance to the clients. As the originator of the organizational vision, the ECE leader needs to have not only the determination to see the proposed policies being implemented correctly, but also the patience, resilient demeanor, intellectual fortitude and organizational calm to allow any slow changes and challenges to take effect so as to improve the efficacy of the ECE site.

\subsection{Leading People in ECE Settings as a Pedagogy Creator}

The role of an ECE leader as a pedagogy creator involves coming up with insights that lead to the generation of new ways of teaching, learning, assessment and curriculum development so as to develop "best practice pedagogy” (Kivunja, 2015b: p. 3). Being a creator of pedagogy involves developing or advocating child-friendly strategies which seek to maximize not only Vygotskyian (Vygotsky, 1929) social constructivist strategies, but also, given the demands of the Digital Economy, Siemen's connectivist strategies (Siemens, 2004; Kivunja, 2014). This role involves recognition that in the creation of pedagogy for ECE, the children's interests must be the prime factor which influences what is created. It also recognizes that children of the current digital age learn best through interconnected peer learning networks, which give them opportunities to develop and utilize their digital fluency skills.

\subsection{Leading People in ECE Settings as a Rights' Advocate}

The role of an ECE leader as a rights' advocate requires the leader to champion the cause of ECE at different levels. Firstly, it requires that the leader advocate for the success of his or her own organization. Secondly, s/he needs to advocate for the improvement in working conditions for his or her colleagues at the particular ECE site. Thirdly, s/he has to advocate for similarly good conditions for people in the ECE industry and community at large. For example, at his or her own site, s/he needs to ensure that staff members are given every opportunity for professional development and career advancement. However, on a broader level, s/he also needs to support the development of the ECE setting as part of a learning community.

\section{How Does Efficient and Effective Leadership Function in an Early Childhood Context?}

In educational contexts, the efficiency criterion usually refers to the need to allocate and utilize educational re- 
sources in a way that optimizes their use. In other words, there is neither waste nor inefficiency in the use of available resources. In contrast, effectiveness is used to refer to the extent to which organizational goals are achieved in the specified planning horizon. For example, studies on educational effectiveness, such as Hattie (2003) and Martinez \& Martinez (1999) use the extent to which learners achieve stated learning outcomes as proxies for teaching effectiveness. When these two criteria are applied to leadership in an ECE setting, we would be looking for leadership which facilitates the provision of quality of service for an ECE setting which would meet the stakeholders' expectations. For example, in Australia, stakeholders' expectations can be seen in the standards to be met which are stipulated in the Early Years Learning Framework for Australia (DEEWR, 2009). Similarly, in New Zealand they are set out in the Te Whariki Framework of the Ministry of Education (NZ-MOE, 1996). Leadership that meets these standards would be seen as meeting the efficiency and effectiveness criteria of the ECE setting.

Thus, efficiency and effectiveness of leadership in an ECE setting would be judged in light of the quality of service stipulated in the relevant documents for the respective jurisdiction. For example, in the Australian document relevant to the ECE setting, quality of service is undergirded by five principles namely "1) secure, respectful and reciprocal relationships; 2) partnerships; 3) high expectations and equity; 4) respect for diversity; and 5) ongoing learning and reflective practice” (Sims \& Hutchins, 2011: p. 19). As for the New Zealand national curriculum document for ECE quality control, the criteria are stated as "1) empowerment; 2) holistic development; 3) family; and 4) community and relationships” (Sims \& Hutchins, 2011: p. 19). The extent to which these are met would indicate the efficiency and effectiveness of leadership as it would approximate provision for the wellbeing of the children and other people in an ECE setting, their sense of belonging, contribution to the ECE setting, communication and exploration.

\section{Conclusion}

The literature reviewed in this paper leads to an understanding that whereas efficient and effective leadership is essential for the success of any educational organization, it is even more vital for the success of an ECE setting. Not only does an ECE setting leader have to plan, organize, lead and control what happens in the setting, s/he has to be a visionary, a team stakeholder, a policy designer, a pedagogy creator and a rights' advocate, all at once. The people, the place and the practices that s/he has to manage and lead involve intricate structural and cultural dynamics, different from a schooling context of learning stages more advanced than the ECE stages. This helps us to understand that an ECE setting is not just another school setting. It looks different, it involves different roles and the leader has to perform functions that are significantly different from those in a primary, or secondary school, or a tertiary institution. The leader's capacity to succeed in the synergies embedded in these structures, roles and functions sets the ECE leader in a class of their own. Navigating the dynamics of these synergies enables the ECE leader to provide for systematic and sustainable transformation of the ECE setting so that people employed in the ECE place can practice their roles efficiently and effectively to enable the children to achieve learning and growing up outcomes for their wellbeing. Thus, leadership in an ECE setting involves, not only providing a transformative vision and enabling governance, but also coming up with organizational strategies, educational outcomes, pedagogy and curriculum, which cater well for the education and wellbeing of the children in the ECE setting. All this needs to be led in concert with the demands of the Digital Economy in which the children are digital natives and the teachers, most likely digital immigrants (Prensky, 2001). This creates an additional challenge to the leadership in an ECE setting to ensure that $\mathrm{s} / \mathrm{he}$ maintains an unrelenting focus on professional development for the existing staff and recruiting new ones that are digitally fluent so as to prevent a situation in which the children in an ECE setting would be literate and their teachers illiterate in digital logic, language and technologies.

\section{References}

Ailwood, J. (Ed.) (2007). Early Childhood in Australia: Historical and Comparative Contexts. Frenchs Forest, NSW: Pearson Education Australia.

Arthur, L., Beecher, B., Death, E., Dockett, S., \& Farmer, S. (2007). Programming and Planning in Early Childhood Settings. (4th ed.). South Melbourne: Cengage Learning Australia.

Barker, C., \& Coy, R. (2004). The Power of Culture: Driving Today’s Organizations. Sydney: McGraw-Hill.

Becker, N., \& Becker, P. (2009). Quality Care for Young Children. How to Turn Early Care Settings into Magical Places. 
Thousand Oaks, CA: Corwin Press.

Belsky, J. (1988). The Effects of Infant Day Care Reconsidered. Early Childhood Research Quarterly, 3, $235-272$. http://dx.doi.org/10.1016/0885-2006(88)90003-8

Brundrett, M., \& Crawford, M. (Eds.) (2008). Developing School Leaders: An International Perspective. London: Routledge.

Bryant, L., \& Gibbs, L. (2013). A Director's Manual: Managing an Early Education and Care Service in NSW. Marrickville, NSW: Community Child Care Co-Operative, Ltd. (NSW).

Caldwell, B. J. (2006). Re-Imagining Educational Leadership. Camberwell, VIC: ACER Press.

Carnes, M. C. (2011). “Setting Students’ Minds on Fire”. Chronicle of Higher Education, 57, 72.

Davis, J. (Ed.) (2010). Young Children and the Environment: Early Education for Sustainability. Port Melbourne, VIC: Cambridge University Press. http://dx.doi.org/10.1017/CBO9780511845390

DEEWR (2009). Belonging, Being and Becoming: The Early Years Learning Framework for Australia. Canberra: Commonwealth of Australia.

Dowling, A., \& O’Malley, K. (2009). Preschool Education in Australia. Policy Brief, December. http://research.acer.edu.au/policy_briefs/1

Ebbeck, M., \& Yim, H. (2009). Rethinking Attachment: Fostering Positive Relationships between Infants, Toddlers and Their Primary Caregivers. Early Child Development and Care, 179, 889-909. http://dx.doi.org/10.1080/03004430701567934

Fligstein, N., \& Freeland, R. (1995). Theoretical and Comparative Perspectives on Corporate Organizations. Annual Review of Sociology, 21, 21-43. http://dx.doi.org/10.1146/annurev.so.21.080195.000321

Follari, L. (2007). Foundations and Best Practices in Early Childhood Education. History, Theories and Approaches to Learning. Upper Saddle River, NJ: Pearson, Merrill Prentice Hall.

Fullan, M. (2000). Change Forces: Probing the Depths of Educational Reform. London: The Falmer Press.

Fullan, M. (2001). The New Meaning of Educational Change (3rd ed.). New York: Teachers College Press.

Fullan, M. (2004). Leading in a Culture of Change: Personal Action Guide and Workbook. San Francisco, CA: Jossey-Bass.

Gillies, R., \& Boyle, M. (2013). Cooperative Learning: A Smart Pedagogy for Successful Learning. http://sydney.edu.au/education_social_work/professional_learning/resources/papers/slc-2013/cooperative-learning.pdf

Hackman, J. R., \& Wageman, R. (2005). A Theory of Team Coaching. Academy of Management Review, 30, 269-287. http://dx.doi.org/10.5465/AMR.2005.16387885

Hammersley, M. (1998). Reading Ethnographic Research: A Critical Guide (2nd ed.). London: Longman.

Hattie, J. (2003). Teachers Make a Difference: What Is the Research Evidence? Proceedings of the ACER Research Conference, Melbourne, 19-21 October 2003.

Johnson, D. W., \& Johnson, F. (2009). Joining Together: Group Theory and Group Skills (10th ed.). Boston, MA: Allyn and Bacon.

Johnson, D. W., \& Johnson, R. T. (1994). Joining Together: Group Theory and Group Skills. Englewood Cliffs, NJ: Prentice Hall.

Kagan, S. (1994). Cooperative Learning. San Clemente, CA: Resources for Teachers, Inc.

Kivunja, C. (2014). Do You Want Your Students to Be Job-Ready with 21st Century Skills? Change Pedagogies: A Paradigm Shift from Vygotskyian Social Constructivism to Critical Thinking, Problem Solving and Siemens' Digital Connectivism. International Journal of Higher Education, 3, 81-91. http://dx.doi.org/10.5430/ijhe.v3n3p81

Kivunja, C. (2015a). Exploring the Pedagogical Meaning and Implications of the 4Cs "Super Skills" for the 21st Century through Bruner's 5E Lenses of Knowledge Construction to Improve Pedagogies of the New Learning Paradigm. International Journal of Creative Education, 6, 1-19.

Kivunja, C. (2015b). Teaching, Learning and Assessment: Steps towards Creative Practice. Melbourne: Oxford University Press.

Kivunja, C., \& Power, A. (2006). A New Dynamics Paradigm for Analyzing Structural and Cultural Dynamics in an Educational Organization. Proceedings of the AARE 2006 International Education Research Conference: Engaging Pedagogies, Adelaide, 26-30 November 2006.

Kouzes, J., \& Posner, B. (2003). The Leadership Challenge (3rd ed.). San Francisco, CA: John Wiley.

Martinez, J., \& Martinez, N. C. (1999). Teacher Effectiveness and Learning for Mastery. The Journal of Educational Research, 92, 33-50. http://dx.doi.org/10.1080/00220679909597607

McCrea, N. L. (2015). Leading and Managing Early Childhood Settings: Inspiring People, Places and Practices. Port Mel- 
bourne: Cambridge University Press.

Mulford, B. (2003). School Leaders: Changing Roles and Impact on Teacher and School Effectiveness. A Paper Commissioned by the Education and Training Policy Division, OECD, for the Activity: "Attracting, Developing and Retaining Effective Teachers”. Paris, April, 2003.

Mulford, W., Silins, H., \& Leithwood, K. (2004). Educational Leadership for Organizational Learning and Improved Student Outcomes. London: Kluwer Academic Press.

NZ-MOE (1996). Te Whariki. He Whariki Matauranga mo nga Mokopuna o Aotearoa. Early Childhood Curriculum. Wellington: Learning Media.

Ochiltree, G. (1994). Effects of Child Care on Young Children, Forty Years of Research. Early Childhood. Study Paper No. 5, Melbourne: Australian Institute of Family Studies.

Pace, R. W. (2002). Organizational Dynamism. London: Quorum Books.

Prensky, M. (2001). Digital Natives, Digital Immigrants, Part 1. On The Horizon, 9, 3-6. http://dx.doi.org/10.1108/10748120110424816

Robbins, S. P., Millet, B., Cacciope, R., \& Waters, M. T. (1998). Organizational Behavior. Sydney: Prentice Hall.

Schein, E. (2005). Defining Organizational Culture. In J. M. Sharfritz, J. S. Ott, \& Y. S. Jang (Eds.), Classics of Organizational Theory (6th ed.). London: Thomson.

Scott, G. (1999). Change Matters: Making a Difference in Education and Training. St. Leonards: Allen Unwin.

Semann, A., \& Soper, R. (2012). Pedagogical Leadership: Exploring New Terrain and Provocations. Reflections, 47, 16-17.

Siemens, G. (2004). Connectivism: A Learning Theory for the Digital Age. Journal of Instructional Technology and Distance Learning, 2.

Silins, H., \& Mulford, B. (2002). Schools as Learning Organizations: The Case for System, Teacher and Student Learning. Educational Administration, 40, 425-446. http://dx.doi.org/10.1108/09578230210440285

Sims, M. (1999). What We Believe Is What We Do. Australian Journal of Early Childhood, 24, 1-5.

Sims, M. (2009). Caring for Young Children: What Children Need. Policy Brief: Translating Early Childhood Research Evidence to Inform Policy and Practice, 15, 1-4.

Sims, M., \& Hutchins, T. (2011). Program Planning for Infants and Toddlers: In Search of Relationships. Castle Hill: Pademelon Press.

Truskie, S. D. (2002). Leadership in High Performance Organizational Cultures. London: Quorum Books.

Vygotsky, L. S. (1929). The Problem of the Cultural Development of the Child. Journal of Genetic Psychology, 36, 415-434. http://dx.doi.org/10.1080/08856559.1929.10532201

Wood, E., \& Attfield, J. (2005). Play, Learning and the Early Childhood Curriculum. London: Paul Chapman Publishing. 